\title{
Morphological Characterization and Identification of Coffea liberica Callus of Somatic Embryogenesis Propagation
}

\author{
Fitria Ardiyani ${ }^{* *}$ \\ ${ }^{1}$ Indonesian Coffee and Cocoa Research Institute, J1. PB. Sudirman 90, Jember Indonesia \\ ${ }^{*}$ Corresponding author: ardiyani.fitria@gmail.com
}

\begin{abstract}
Compared with other types of coffee, Liberica coffee is more difficult to be propagates using clonal methods. Meanwhile, demand for planting materials and consumption of this type of coffee is increasing lately. The objective of this paper is to present results of the work on morpological characterization of Liberica coffee (Coffea liberica) callus produced by somatic embryogenesis propagation. This research used $C$. liberica Arruminensis clone. This clone was one of Liberica coffee clones which had superior taste. Main activitis carried out in this experiment were explant sterilization, explant induction and histological analysis on the callus produced. The result of this research showed that non embryogenic callus was higher $(72 \%)$ than embryogenic callus $(28 \%)$. The callus description can be used to identify type and characteristic of the callus. Therefore, it can be a parameter to choose type of callus for propagation material. This is important because choosing the right callus is determine of the succesfully process of Liberica somatic embryogenesis.
\end{abstract}

Keywords: somatic embryogenesis, Liberica, embryogenic, non-embryogenic

\section{INTRODUCTION}

Coffee is one of the estate crop commodity which has high commercial value in Indonesia and in the world. Coffee is grown by smallholders, private estate and goverment estate enterprise. There are many kinds of coffee grown in Indonesia i.e. Robusta, Arabica, Excelsa, and Liberica coffee. Robusta and Arabica coffee have high contribution in Indonesian coffee, namely $97 \%$, whereas Liberica and Excelsa has only about 3\%. However, at present, Liberica coffee begins to be grown more extensive because it has some superiorities such as its specific taste and can be grown in marginal soil especially in peat soil (Hulupi, 2014). In Indonesia, Liberica coffee has been developed in Kalimantan, Sumatera and some areas of Java. Liberica coffee is grown by many farmers in swampy area, the majority of which is peat soil like in Jambi (Tanjung Jabung Barat Regency). Liberica coffee is also planted in Central Kalimantan, West Kalimantan, North Sumatera, Lampung, and in East Java. In Malaysia this type of coffee has relatively high price, therefore it is grown like other types of coffee.

Increase of Liberica coffee acreage in many regions cause increasing demand for plant material, especially because Liberica coffee is more difficult to be propagated than other types. Liberica coffee is usually propagated by seeds and difficult to be propagated by clonal methods. Propagation by seed or generative propagation has a weakness that characteristics of progenies are not similar with their parent. On the other hand in clonal or vegetative propagation system the progenies are uniform and 
their characteristics are similar with their parent (Mangoendidjojo, 2003). Clonal propagation is done by cutting, grafting, and tissue culture. Recently one of the propagation system is by in vitro culture.

One of tissue culture technique generally used in plant propagation is somatic embryogenesis (SE) which is a process of development of somatic cell to complete plant through the stadium of embryo formation without melting of gamete cells (Santos et al., 2006). Toonen \& de Vries (1996) also stated that $\mathrm{SE}$ is propagation process in which somatic cell grown in controlled condition can developed into embryogenic cell, and after a series of morphological and biochemical changes can produce embryo somatic (clonal embryo) that genetically the same with its parent. Propagation of coffee by means of SE method has been done and published for the first time by Staritsky (1970). SE of coffee also can be obtained using a protocol that has been published (Dublin, 1981).

Response of plant propagation using SE method is in form of callus. Callus is preliminary result in morphogenesis, either by organogenesis or embryogenesis. The end result of this callus is planlet (Thorpe, 1981). The success of callogenesis into planlet depend on condition of explant, medium and environment. Explant in coffee SE is leaf. According to Priyono (2004) there were 17 coffee species which had been propagated using SE method, but from those species only 9 coffee species that could produce somatic embryo. Beside explant, plant medium has significant influence on the success of coffee SE. Plant medium has to contain macro nutrients, micronutrients, vitamins, minerals and plant growth regulator in each step of coffee SE. Environmental factors such as temperature, humidity, and light also has influence on callogenesis of coffee explant.
Callus consists of several types. Sutjahjo (1994) explained that there are two types of callus formed in in vitro culture namely embryogenic callus and non embryogenic callus. Embryogenic callus is callus that has the potential to regenerate into plant, while non embryogenic callus is callus that has no potential to regenerate into plant. Accuracy in determining type of callus has high influence on the success of coffee SE, because non embryogenic callus will not formed a plant. Embryogenic and non embryogenic callus has different characteristics. The difference can be obtained from morphology and cell anatomy. In this experiment, characteristic of embryogenic and non embryogenic calli of Liberica coffee is studied in order to minimize failure in the process of embryogenic callus selection.

\section{MATERIALS AND METHODS}

Research was carried out in Laboratory of Biotechnology of Indonesian Coffee and Cocoa Research Institute (ICCRI). This research used $C$. liberica clone Arruminensis. This clone was one of Liberica coffee clones which had superior taste. Main activities carried out in this experiment were explant sterilization, explant induction and histological analysis on the callus produced.

Explant used in this experiment was young leaf (flush) that has been fully opened. Sterilization was done using fungicide of $2 \mathrm{~g} / \mathrm{L}$, sodium hypochloride solution at $2 \mathrm{~g} / \mathrm{L}$ and alcohol $90 \%$ as sterilant. Time needed for each sterilant was 20 minutes for fungicide, 30 minutes for sodium hypochloride, and for alcohol it was only rinsing during several second. After sterilization the explant was planted on the medium for callus induction using basic medium Murashige and Skoog (MS) added with auxin (2.4D) $1.08 \mathrm{mg} / \mathrm{L}$ as growth hormone. The culture was incubated during 2-3 months with subculturing every 2 weeks on the same medium. 
Callus produced by induction stage/ step of explant could be divided into embryogenic callus and non embryogenic callus. Those callus was analysed histologically in Laboratory of Embryology of Gadjah Mada University. Histological analysis of the callus used parafin method with single colouring. According to Jensen (1962) for observing embryo development, preserved object was made using paraffin method, double coloured with safranin $1 \%$ and fast green $1 \%$ in alcohol. This analysis was general analysis used for detecting one part of plant cell. Histological preparation was made from callus fixed with formalin acetic acid alcohol and then incubated during 24 hours. Afterwards it was rinsed and dehidrated using serial of alcohol solution (70-100\%) during 24 hours followed by infiltration which was done with pure paraffin at constant temperature of $57^{\circ} \mathrm{C}$ during 24 hours. The callus was further embedded using pure paraffin prepared in form of block. The preparation was further cut using rotary microtome. The callus preparation was further covered with glass and dried on hot plate at the temperature of $45^{\circ} \mathrm{C}$. The preparation was further observed under the light microscope.

\section{RESULTS AND DISCUSSION}

Somatic embryogenesis of Liberica coffee has been developed as one of alternative for clonal propagation. Propagation of Liberica coffee by SE method could be done like SE propagation in Robusta and Arabica coffee, although there was difference in the composition of medium and incubation time at each step of propagation (Ardiyani, 2014). The first step in propagation of Liberica coffee by SE method was sterilization.

Explant of Liberica coffee leaf has to be sterilized to prevent contamination during culturing process. Sterilization of explant could be done by means of two methods namely by mechanical and chemical methods (Hendaryono \& Wijayani, 1994). For young explant (meristemetic tissue) such as leaf of Liberica coffee generally sterilization was done by chemical method. Some sterilants that could be used are sodium hypochloride, calcium hypochloride, hydrogen peroxide, and silver nitrate, fungicide, and bactericide. In this experiment sterilant used was fungicide followed by sodium hypochloride, and alcohol.

Figure 1 showed that by step wise sterilization, clean explant obtained was $70 \%$, while $30 \%$ explant was contaminated by fungus and bacteria. Sterilization should be done at the right way because explant and contaminant are organisms, therefore the use of sterilant should remove contaminant but it should not damage the explant. In the sterilization of Liberica coffee several sterilants used were fungicide, sodium hypochloride, and alcohol. Fungicide had the function as sterilant for fungus while sodium hypochloride was sterilization agent for explant against bacteria. Sodium hypochloride had been used at different concentration, i.e. 1-10\% during 5-30 minutes (Darmono, 2003) or 1-2\% during 7-15 minutes (Gunawan, 1987), and 5-10\% during 5-10 minutes (Hendaryono \& Wijayani, 1994). Alcohol was used as sterilant for rinsing of explant at the last step. Fungus was usually killed by $90 \%$ alcohol, while using $70 \%$ alcohol the fungus was still alive (Gunawan, 2007). Step wise sterilization using those sterilant could sterilize explant of Liberica coffee leaf during 2-3 months until it grew and developed into callus. The growing explant had characteristic of green leaf part and existence of callus or small whitish particles in a part of explant (Murni, 2010).

Explant of Liberica coffee was incubated on solid culture medium with Murashige \& Skoog (MS) basic medium added with several nutrients. From the incubation 


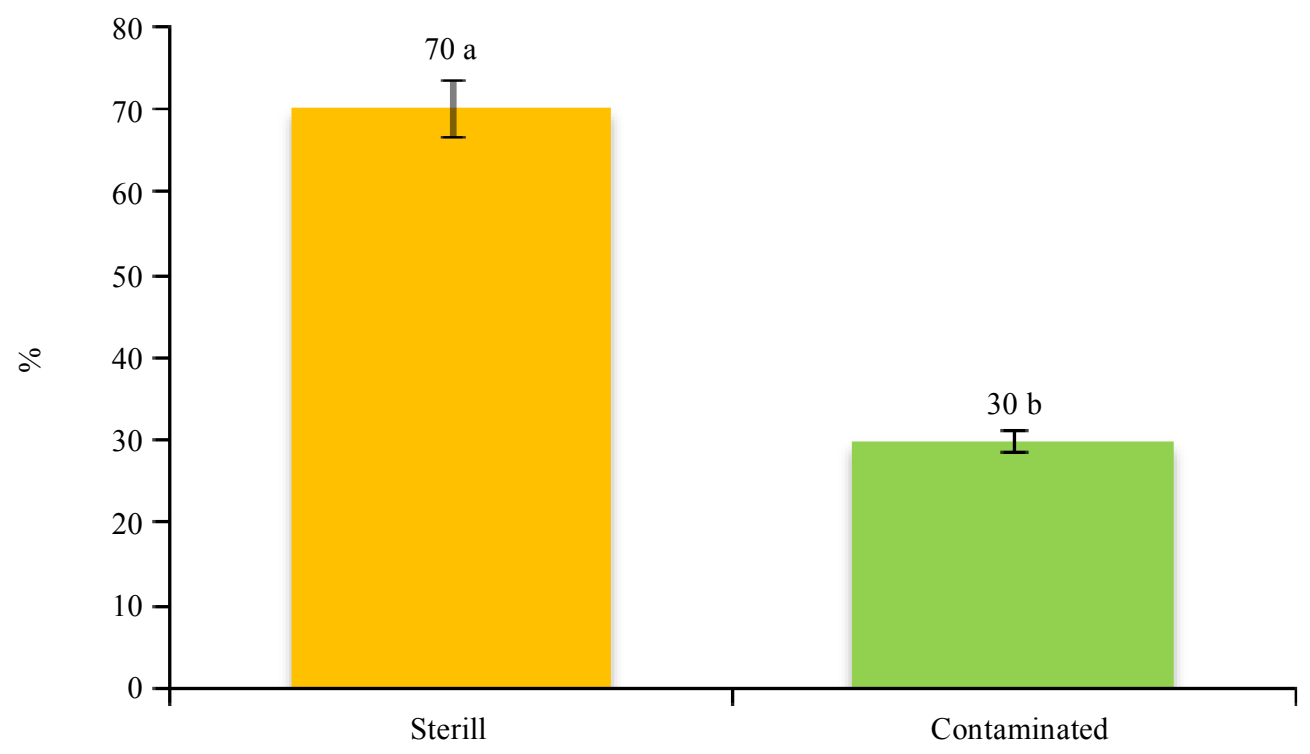

Figure 1. Effect of step wise sterilization on contaminated explant of Liberica coffee after induction

process several types of callus were obtained (Figure 2). Callus of Liberica coffee consisted of embryogenic callus (28\%) and non embryogenic callus (72\%). Embryogenic callus was formed less than that of non embryogenic. One of the reason that non embryogenic callus was more exist than embryogenic one was due to degradation of the cells of embryogenic callus by phenolic substance formed as side effect of callus formation process (Alemanno et al., 1996).

Basically all explant had potential to grow into embryogenic callus, but apparently only small number of the explants may grow into embryonic callus (Onay, 2000). This condition was related to totipotence characteristic owned by each cell in the explant. Not all of the cell could grow and developed into new individual. Onay (2000) mentioned that one of the reason of formation of embryogenic callus was plant growth regulator which could modify cell to form embryogenic callus. Generally application of plant growth regulator on in vitro culture could induce cell division and produced callus or it caused gen modification so that the cell undergo morphogenesis and differensiation including somatic embryogenesis (Street, 1973).

Among several components of plant medium, plant growth regulator was one of the important element that determine the success of callus growth. In Liberica coffee somatic embryogenesis, addition of auxin to the medium, in this case $2.4-\mathrm{D}$ at $1.08 \mathrm{mg} / \mathrm{L}$ stimulated explant growth into embryogenic callus. The nutrient requirement of explant could be supplied by nutrients in the medium accurately, either the substance its self or its concentration (Fambrini et al., 2003). In addition auxin in general has also the function to increase the quantity of embryogenic cells by means of stimulating multiplication cell to produce proembryonic mass (Raghavan, 1986). The success of 2.4-D in inducing explant to produce embryogenic callus was also observed in Shorea pinanga plant (Yelnititis, 2007). 


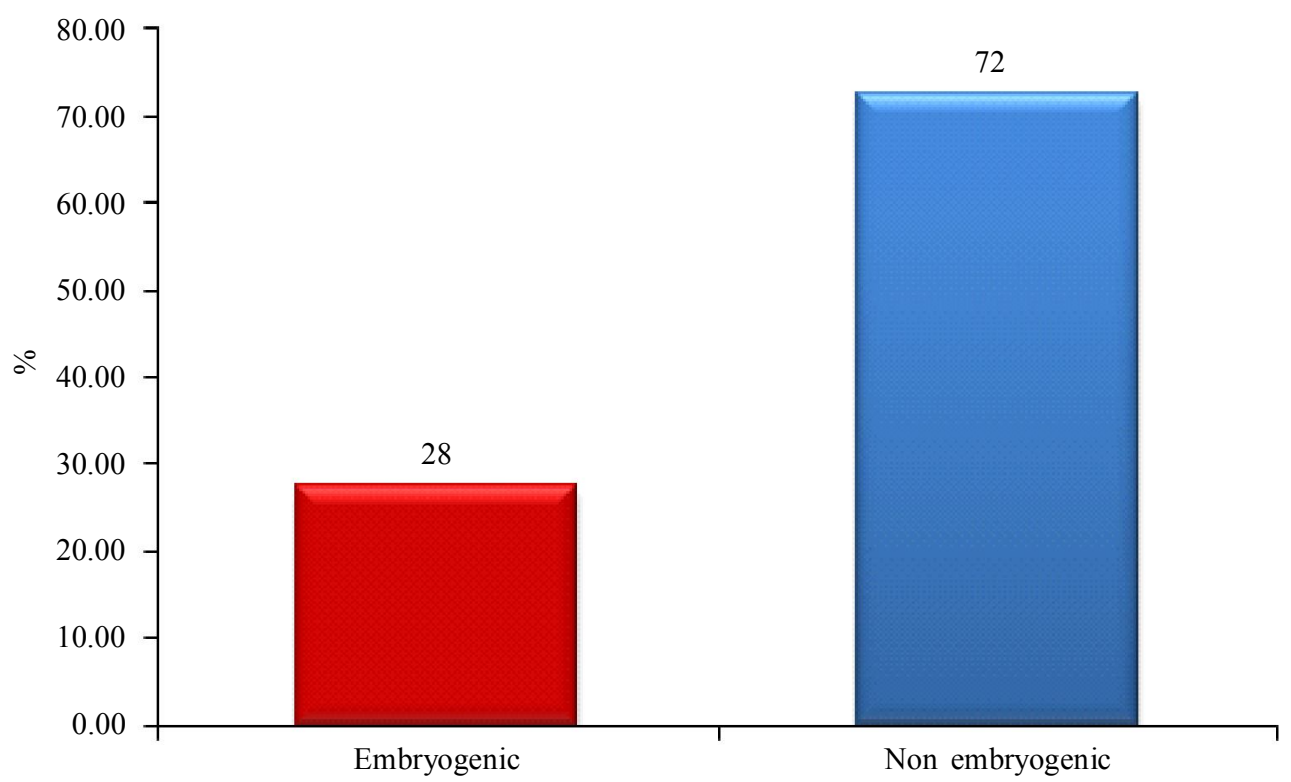

Figure 2. Percentage of embryogenic and non-embryogenic callus of Liberica coffee after induction and incubation

From morphological point of view according to Bhojwani \& Razdan (1983) callus cell produced from tissue culture could be distinguished into two types. The first type was cell with many big vacuoles, which is usually less capable to produce embryo (non embryogenic), while the second type was cell with many cytoplasm, usually had the ability to produce embryo (embryogenic). In Liberica coffee the difference between embryogenic callus and non embryogenic was significant because both type of callus would grow together and became one part. However there was some specific characteristics which distinguish between embryogenic and non embryogenic callus of Liberica coffee (Figure 3).

Callus of Liberica coffee either embryogenic or non embryogenic had visual characteristic which could be distinguished. Embryogenic callus (Figure 3a) was more friable, light, glossy, and consisted of separated individuals. Observation under the microscope embryogenic callus like a clumps of water.
Non embryogenic callus (Figure 3b) was more compact (less friable), dark brown, scemed hard cluster, and did not form individual. Observation under the microscope revealed that non embryogenic callus looked like group of cotton, moist and united into cluster. Non embryogenic callus had a tendency to have brown colour because its regeneration property has decreased (Hutami, 2008). Browning of non embryogenic callus could also due to content of phenol and activity of polyphenoloxidase (Nisa \& Rodinah, 2005).

Embryogenic and non embryogenic callus in other plant had similar characteristic with that of Liberica coffee callus. In rice plant, embryogenic callus usually was characterized by white yellowish colour, glossy, and friable (easily separated to form fragments). On the other hand, non embryonic callus had yellow brownish colour, rather pale and moist so that it was difficult to be separated (Peterson \& Smith, 1991). In soybean, plant embryogenic callus had characteristics of yellow colour with soft texture, friable, with 

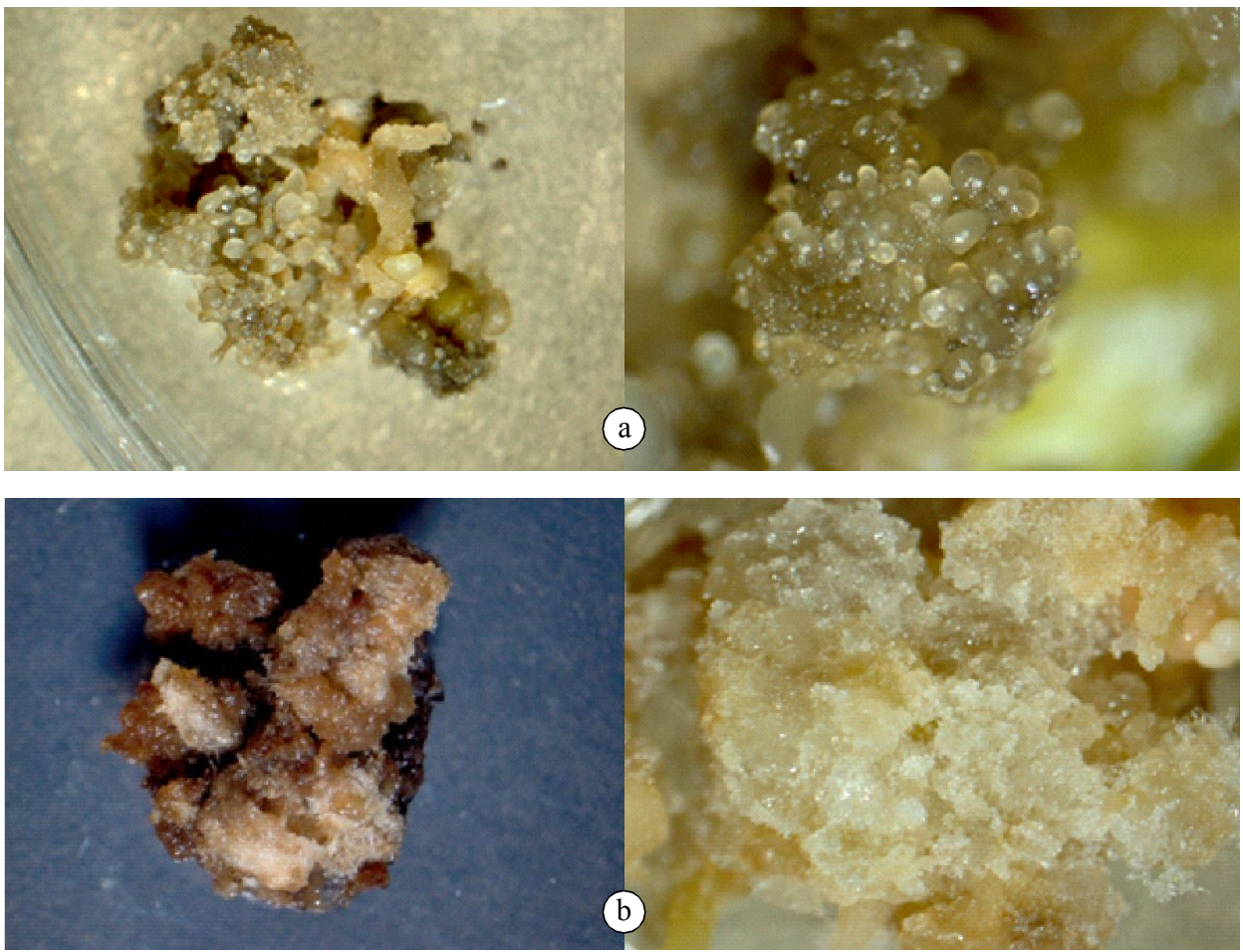

Figure 3. Embryogenic calli (a) and non embryogenic calli (b) of Liberica coffee

globular structure, and transparant (Khumaida $\&$ Handayani, 2010).

Embryogenic callus had separated structure and tended to develop into embryos. In embryogenic callus the cells and tissue could grow optimum and developed in accordance with its function. In non embryonic callus, however, its cell could not develop according to its function, even some of them were damaged and could not develop into embryos (Figure 4).

From histological observation, it appeared that in embryogenic callus (Figure 4a) the tissue composed of living cells (plasm and nucleus looked clear), composed of close meristematic tissue, contained amylum, many small shoots, and candidate of vascular bundles, which was composed of more compact tissue with thicker cell wall Cells in the edge of callus consisted of small cells that had clear nucleus and the cytoplasm was solid. The characteristics of this cell was similar with the characteristics of embryogenic or meristematic cells (Utami et al., 2007).

In non embryonic callus (Figure 4b) it appeared that most of the cells had been degenerated so that many cell walls were destructed, cells were dead, nuclei and protoplasm were absent, whereas tissue was composed of cells located far from each other, and only some cells that still contained amylum. Due to that condition, non embryonic callus could not grow and develop further in SE. The condition of cells of each callus type would have an impact on further step of callus, i.e. formation of embryo. Embryogenic callus with good condition of cell supported the formation of embryo. On the other hand, in non embryogenic callus cell that was incomplete caused the callus could not grow and develop into embryo.

From the illustration on visual morphology and condition of cells composing callus characteristic or type of callus whether it 

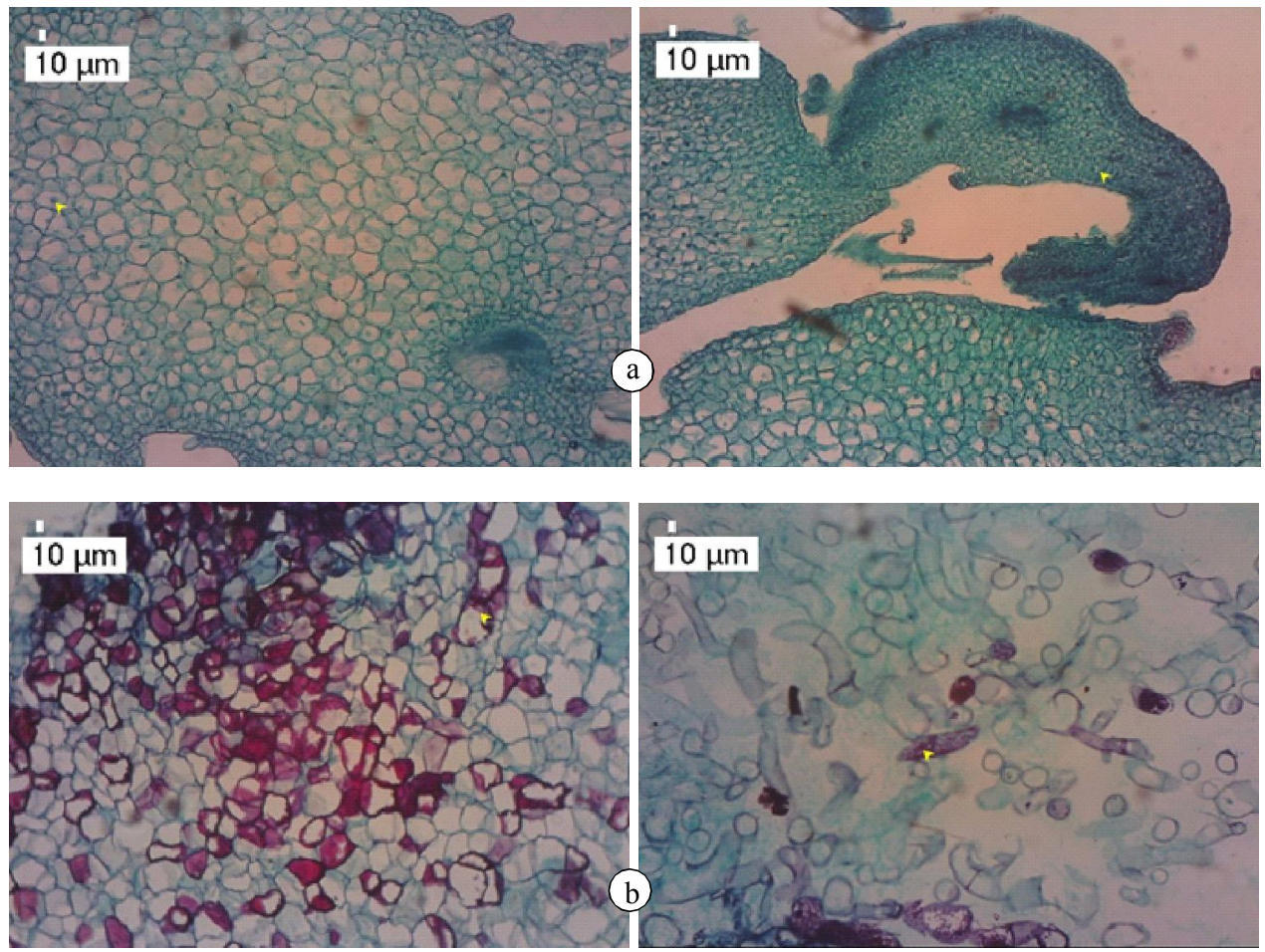

Figure 4. Cell histology of embryogenic calli (a), and non embryogenic calli (b) of Liberica coffee

was embryogenic or non embryogenic could be distinguished. This result could assist in determining type of suitable callus as material for propagation to form embryos of Liberica coffee.

\section{CONCLUSION}

1. Step wise sterilization (fungicide, sodium hypochloride and alcohol) could produce steril explant as much as $70 \%$ and $30 \%$ contaminated explant.

2. Culture medium added with 2.4-D hormone $1.08 \mathrm{mg} / \mathrm{L}$ could produce $28 \%$ embryogenic callus and $72 \%$ non embryogenic callus.

3. Embryogenic callus of Liberica coffee had visual characteristic of friable, glossy and consisted of separated individual, while non embryogenic callus was more compact (non friable), dark brown, grew into one cluster, look hard and did not form individuals.
4. Histologically embryogenic callus of Liberica coffee had tissue that was arranged from close meristematic tissue, contained visible amylum, had many shoot and vascular bundle candidates. On the other hand in non embryonic callus most of the cells had been degenerated, the cell died because nucleus and plasma were absent, tissue contained only a view of cell showing amylum content.

\section{REFFERENCES}

Alemano, L.; M. Berthouly \& N. Michaux-Ferriere (1996). Histology of somatic embryogenesis from floral tissue culture. Plant, Cell, Tissue and Organ, 46, 187-194.

Ardiyani, F. (2014). Potensi perbanyakan kopi Liberika dengan menggunakan metode somatik embriogenesis. Warta Puslitkoka, 26, 1, 14-16.

Bhojwani, S.S. \& M.K. Razdan (1983). Plant Tissue Culture Theory and Practice. Elsevier. Amsterdam. 
Darmono, D.W. (2003). Menghasilkan Anggrek Silangan. Penebar Swadaya. Jakarta.

Dublin, P. (1981). Embryogenèse somatique directe sur fragments de feuilles de caféier Arabusta. Café Cacao Thé, 25, 237-242.

Fambrini, M.; G. Cioini; A. Conti; V. Michelotti \& C. Pugliesi (2003). Origin and development in vitro of shoot buds and somatic embryos from intact roots of Helianthus annuus x $H$. tuberosus. Annales Botany, 92, 1, 145-151.

Gunawan, L.W. (1987). Teknik Kultur Jaringan. Laboratorium Kultur Jaringan Tanaman PAU Bioteknologi. IPB. Bogor.

Hartmann, H.T.; D.E. Kester; F.T. Davies Jr \& R.L. Geneve (1997). Plant Propagation: Principles and practices: $6^{\text {th }}$ Edition. Prentice Hall. New Jersey.

Hendaryono, D.P.S. \& A. Wijayani (1994). Teknik Kultur Jaringan Pengenalan dan Petunjuk Perbanyakan Tanaman secara Vegetatif-Modern. Kanisius. Yogyakarta.

Hulupi, R. (2014). Libtukom: Varietas kopi Liberika anjuran untuk lahan gambut. Warta Puslitkoka, 16, 1-6.

Hutami (2008). Ulasan masalah pencoklatan pada kultur jaringan. Jurnal Agro Biogen, 4, 83-88.

Jensen, W.A. (1962). Botanical Histochemistry. W.H. Freeman and Co. San Francisco, California.

Khumaida, N. \& T. Handayani (2010). Induksi dan proliferasi kalus embriogenik pada beberapa genotipe kedelai. Jurnal Agronomi Indonesia, 38, 19-24.

Mangoendidjojo, W. (2003). Dasar-dasar Pemuliaan Tanaman. Kanisius. Yogyakarta.

Murni, P. (2010). Embriogenesis somatik pada kultur in vitro daun kopi robusta (Coffea canephora var. Robusta Chev.) Biospecies, 2, 22-26.
Nisa, C. \& Rodina (2005). Kultur jaringan beberapa kultivar buah pisang (Musa paradisiaca L.) dengan pemberian campuran NAA dan kinetin. Jurnal Bioscientiae, 2, 23-36.

Onay, A. (2000). Histology of somatic embryogenesis in cultured leaf explants of pistachio (Pistacia vera L.). Turkish Journal of Botany, 24, 91-95.

Peterson, G. \& R. Smith (1991) Effect of abscicic acid and callus size on regeneration of American and international rice varieties. Plant Cell Reports, 10, 35-38.

Priyono (2004). Kultur in vitro daun kopi untuk mengetahui kemampuan embriogenesis somatik beberapa spesies kopi. Pelita Perkebunan, 20, 110-122.

Raghavan, V. (1986). Embryogenesis in Angiosperm: A Developmental and Experimental Study. Cambridge Univ. Press. Cambridge.

Safitri, R.R.E; R.S. Wulandari \& H. Darwati (2013). Penambahan ragi terhadap multiplikasi subkultur tunas manggis (Garcinia mangostana) secara in-vitro. Jurnal Hutan Lestari, 1, 336-342.

Santos, K.G.B.; J.E.A.Mariath; M.C.C. Moco \& M.H.B. Bodanese-Zanettini (2006). Somatic embryogenesis from immature cotyledons of soybean (Glycine max (L.) Merr.): Ontogeny of somatic embryos. Brazilian Archieves Biological Technology, 4, 49-55.

Staritsky, G. (1970). Embryoid formation in callus tissues of coffee. Acta Botanica Neerlandica, 19, 509-514.

Street, H.E. (1973). Plant Tissue and Cell Culture. University of California Press. Los Angeles. California.

Sutjahjo, S.H. (1994) Induksi Keragaman Somaklonal ke Arah Ketenggangan Terhadap Keracunan Aluminium pada Tanaman Jagung. Disertasi, Progam Pascasarjana, IPB. 
Thorpe, T.A. (1981). Plant Tissue Culture Methods and Applications in Agriculture. Academic Press. New York.

Toonen, M.A.J. \& S.C. de Vries (1996). Initiation of somatic embryos from single cells. pp. 173-177. In: T.L. Wang \& A. Cuming (Eds.). Embryogenesis the Generation of Plant. Bios Scientific Publishers Limited. Oxford.
Utami, E.S.W.; I. Soemardi; Taryono \& E. Semiarti (2007). Embriogenesis somatik anggrek bulan Phalaenopsis amabilis (L.): struktur dan pola perkembangan. Berkala Penelitian Hayati, 13, 33-38.

Yelnititis (2007). Induksi embrio somatik Shorea pinanga Sheff dengan 2,4-D dan NAA. Jurnal Penelitian Tanaman Hutan, 4, 235-243

$* * 0 * *$ 